\title{
Innovation Capabilities and Market-Based Competitive Advantage of Indonesian Manufacturing Companies
}

\author{
Andi Wijayanto ${ }^{1}$, Agus Hermani D. Seno ${ }^{2}$ \\ \{andibilt@gmail.com ${ }^{1}$ \} \\ Universitas Diponegoro, Indonesia ${ }^{1,2}$
}

\begin{abstract}
Innovation capability is an important factor for a company's competitive advantage. This study aims to prove the effect of innovation capability on market/industry-based competitive advantage in manufacturing companies in Indonesia. The study population was all manufacturing companies that listed on the IDX. The research sample was taken by purposive sampling by selecting manufacturing companies that are committed to building innovation capabilities through investment in research and development (R\&D). The data collection method used documentation techniques. The data source is the company's financial statements. annual reports, summaries of listed companies, and the IDX Facts Book. The data analysis technique includes descriptive and inferential analysis using linear regression analysis. The results of the analysis conclude that innovation capability has a positive and significant effect on Operating Liability Leverage; innovation capability has a significant negative effect on Inventory Turnover (ITO) and Receivable Turnover (RTO). The innovation capability has no significant effect on Financial Leverage and Excess Funds. Expenditures for companies in R\&D must be able to substantially increase innovation capabilities so that they have an impact on competitive advantage.
\end{abstract}

Keywords: Innovation Capabilities, Market-Based Competitive Advantage, R\&D, Power Over Suppliers, Power Over Customers, The Credibility of Expected Threat of Retaliation

\section{Introduction}

Innovation is an issue that has received increasing attention in the last decade. The development of information and communication technology has proven that innovation has changed the ways people do things in life. Old ways will be replaced by new ways because of innovation. So that innovation is also called creative destruction. This phenomenon also proves the opinion of Joseph E. Schumpeter in 1934 who stated that the key to growth is innovation. According to him, innovation determines the progress of a nation more than resources [1].

Since the 1990s, many innovations have been studied in relation to the achievement of the company's sustainable competitive advantage. Competitive Advantage is an advantage that a company has because it implements a strategy that is successful and difficult for competitors to imitate [2]. According to the theory of Market-Based View (MBV), pioneered by Michael E. Porter through Porters Five Forces model, the performance of a company that is superior will depend on the company's unique position in a competitive environment. The five strengths of companies in this competitive environment are the bargaining power of buyers, 
the threat of new entrants, the bargaining power of suppliers, the threat of substitutes products or services and rivalry among existing firms [3].

The innovation capability of a company is believed to be the key to competitive advantage. Innovation capability is a factor that determines success, performance and competitive advantage [4].

The next development gave rise to a theory called Dynamic Capabilities View (DCV). This theory was put forward by Teece \& Pisano [5]. Dynamic Capabilities are "the ability of companies to integrate, build and reconfigure their internal and external competencies in the face of rapid environmental changes". The components of Dynamic Capabilities include Sensing opportunities and threats, Seizing opportunities, and reconfiguration, adaptive capability, absorptive capability, and innovative capability [6][7].

The relationship between innovation capabilities and competitive advantage was suggested by Ou et al. [8] which states that Dynamic Capabilities in R\&D activities, a proxy for innovation capabilities, contribute to a company's competitive advantage. Several previous studies have highlighted the relationship between innovation capabilities and competitive advantage. One of them is research by Delgado et al. [9]. Delgado et al. [9] in their study of 82 scientific papers concluded that innovation capability affects a company's success in gaining competitive advantage. Breznik \& Lahovnik [10] research concludes that innovation ability, managerial capability and human resource capability are the most relevant capabilities that enable companies to successfully adapt to changing environments and strong market demands. Aziz \& Samad [11] prove that innovation has a strong positive impact on competitive advantage. Companies must invest in innovation to gain competitive advantage.

This study aims to prove the influence of innovation capability on Competitive Advantage with market/industry indicators which include the power over suppliers, power over customers, and the credibility of expected threat of retaliation.

The research hypothesis is as follows: H1: Innovation capability has a significant effect on Operating Liability Leverage (OLL); H2: Innovation capability has a significant effect on Inventory Turnover (ITO); H3: Innovation capability has a significant effect on Receivables Turnover (RTO); H4: Innovation capability has a significant effect on Financial Leverage (FL); H5: Innovation capability has a significant effect on Excess Funds (ExF).

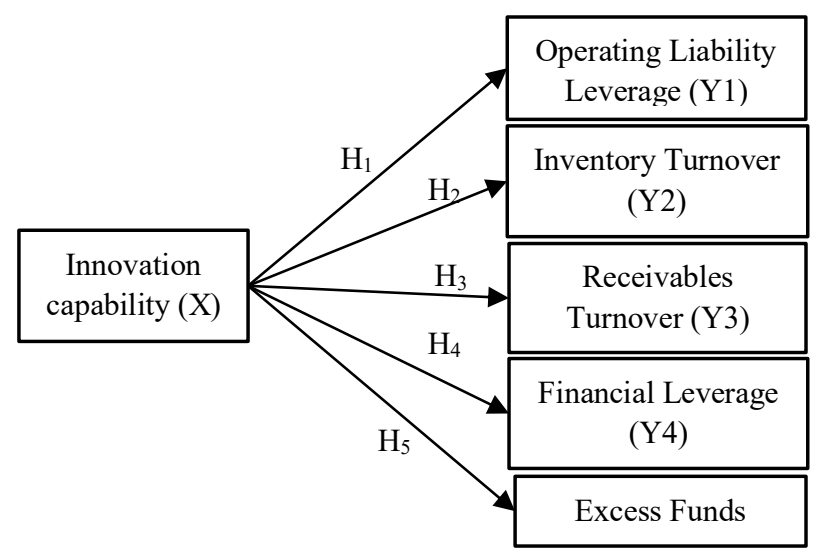

Fig. 1. Hypothesis Model. 


\section{Method}

Innovation capability is the company's ability to develop new products and/or markets, by aligning strategic innovative orientation with innovative behaviours and processes [12][13]. Innovation capability is measured by the percentage increase in Research and Development (R\&D) activities.

Market-Based Competitive Advantage is an advantage a company has due to industry/market factors, including the bargaining power of buyers, the bargaining power of suppliers, and the credibility of expected threat of retaliation. The indicators used to measure Power over suppliers are Operating Liability Leverage (OLL) and Inventory Turnover (ITO). Power over customers is measured by the Receivables Turnover (RTO) indicator. The credibility of expected threat of retaliation is measured using the Financial Leverage (FL) and/or Excess Funds (ExF) indicators.

The study population was all publicly traded manufacturing companies in Indonesia. Based on the 2018 IDX Facts Book, the number of manufacturing companies that went public in Indonesia was 166 companies. The sample is determined purposively where the sample firm must expose its R\&D expenses in its financial statements. The availability of this data allows researchers to measure innovation capabilities. With these considerations, a sample of 35 companies was obtained. The data collection method uses documentation techniques. The data source is the Indonesia Stock Exchange. The data analysis technique used linear regression analysis.

\section{Result and Discussion}

Based on the results of testing the research hypothesis, it can be summarized as follows:

Table 1. Summary of Hypothesis Testing Results

\begin{tabular}{|l|c|c|c|c|}
\hline \multicolumn{1}{|c|}{ Path } & $\mathbf{T}_{\text {Test }}$ & Sig. & $\mathbf{T}_{\text {Table }}$ & Hypothesis \\
\hline $\begin{array}{l}\text { Innovation capability } \rightarrow \text { Operating Liability } \\
\text { Leverage }\end{array}$ & 2.075 & .039 & 1,960 & Accepted \\
\hline Innovation capability $\rightarrow$ Inventory Turnover & -3.063 & .002 & 1,960 & Accepted \\
\hline Innovation capability $\rightarrow$ Receivable Turnover & -2.581 & .011 & 1,960 & Accepted \\
\hline Innovation capability $\rightarrow$ Financial Leverage & -.989 & .324 & 1,960 & Rejected \\
\hline Innovation capability $\rightarrow$ Excess Funds & -1.408 & .161 & 1,960 & Rejected \\
\hline
\end{tabular}

The results of the regression analysis show that innovation capability has a significant effect on OLL. The direction of the influence is positive where an increase in innovation capabilities will increase the company's strength against suppliers as indicated by the increase in OLL. Innovation capability has a significant effect on ITO. The direction of the influence is negative where an increase in innovation capability will reduce the company's strength against suppliers as indicated by a decrease in ITO. Innovation capability has a significant effect on RTO. The direction of the influence is negative where an increase in innovation capability will reduce the firm's strength against suppliers as indicated by a decrease in RTO. Innovation capability has no significant effect on Financial Leverage and Excess Funds.

One of the components of dynamic capabilities that play an important role for a company's competitive advantage is the capability to innovate. This capability is increasingly 
relevant in the current situation or era where old ways will continue to be replaced by new ways or known as the era of disruption.

The company's efforts to build and maintain these capabilities require investment [14][15][16]. Investments in the form of expenses are inevitable because the company is in a competitive and constantly changing business environment. If the company is in the same operating routine from time to time, this is clearly dangerous [17]. In an effort to build innovation capabilities, companies will invest heavily in research and development activities.

An innovative company is believed to have a competitive advantage in the market. Market-based competitive advantage is shown through several indicators, namely having power over suppliers, power over customers, and the credibility of expected threat of retaliation.

A company that has a competitive advantage means that it is able to exert power over suppliers to obtain favourable trading terms for the company. The indicators used to measure the power over suppliers in this study are OLL and ITO. The results of this study concluded that innovation capability has a positive and significant effect on OLL. Companies that intensively build innovation capabilities through $R \& D$ will have greater power over suppliers. Suppliers' trust in the company will increase, thereby increasing operating liabilities. This conclusion supports the results of the study Delgado et al. [9] as well as the research results of Adeniran and Johnston [18]; Aziz and Samad [11]. This conclusion is different from the results of research Ou et al. [8] which found that innovation capabilities through investment in $\mathrm{R} \& \mathrm{D}$ had no significant effect on competitive advantage.

The results of this study conclude that innovation capability has a significant effect on ITO. The direction of the influence is negative, where the greater the company's spending in R\&D, the lower the ITO ratio. The more intensively the company builds innovation capabilities, the lower the inventory turnover. This shows that the greater the company's efforts to build innovation capabilities, the greater the expenditure on R\&D activities. Thus, the available funds to produce goods and or services will decrease, thereby reducing the value of the cost of goods sold. The results of this study contradict the results of research by Aziz and Samad [11]; Li and Liu [19] which concluded that innovation capability has a positive effect on competitive advantage.

Furthermore, companies that have competitive advantages are marked by strong bargaining power over customers. The results of this study concluded that innovation capability has a significant effect on RTO with negative influence. This means that the greater the company's expenditure in R\&D, the lower the RTO ratio. The more intensively the company builds innovation capabilities, the lower the accounts receivable turnover is. Introducing the company's innovations to customers requires a series of costly promotional activities, one of which is credit sales. The more innovation the company has, the greater the sales credit is given to introduce the company's innovation. The results of this study contradict the results of research by Aziz and Samad [11]; Li and Liu [19] which concluded that innovation capability has a positive effect on competitive advantage.

A company with a competitive advantage means that it has the ability to retaliate against attacks by newcomers or existing competitors. This capability can be measured using the Financial Leverage (FL) and Excess Funds (ExF) indicators. The results of this study indicate that innovation capability has no significant effect on FL. This means that the increased innovation capability does not affect the company's ability to obtain loans in order to counterattack. Large expenses in R\&D activities can affect creditor confidence, especially if it is seen that these expenses do not show a significant impact on increasing the company's capability. This conclusion supports the results of the study Ou et al. [8] which found that 
innovation capabilities through investment in R\&D had no significant effect on competitive advantage.

To be able to perform retaliation, companies must have large funds. The results of this study indicate that innovation capability has no significant effect on ExF. This means that increasing innovation capability does not affect the amount of excess funds owned by the company. Large expenses in R\&D activities will not change anything if these expenses do not show a significant impact on increasing the company's capabilities. This conclusion supports the results of the study $\mathrm{Ou}$ et al. [8] which found that innovation capabilities through investment in R\&D had no significant effect on competitive advantage.

The company has sacrificed a lot of money to increase its innovation capabilities. Therefore, this investment must have an impact on increasing innovation capabilities. Without an increase in innovation capabilities, the company's spending in R\&D will be wasted, even having a negative impact on competitive advantage. As stated by Eisenhardt and Martin [20]; Zahra et al. [21] that having Dynamic Capabilities does not result in superior company performance if the substantive capabilities built are mediocre so that no advantage will arise.

\section{Conclusion}

The innovation capability shows a positive and significant effect on Operating Liability Leverage. Meanwhile, the influence of innovation capability on ITO and RTO is negative and significant. This study found that innovation capability did not have a significant effect on the company's ability to retaliate as indicated by the ratio of Financial Leverage and Excess Funds. Based on the research findings, it is suggested that companies ensure that expenditures on $R \& D$ should be able to substantially increase innovation capabilities so that they have an impact on competitive advantage. Future research can use different perspectives in identifying the main factors that shape competitive advantage, especially in the current disruptive era.

\section{References}

[1] J. A. Schumpeter, Essays: On entrepreneurs, innovations, business cycles, and the evolution of capitalism. Transaction Publishers, 1991.

[2] J. Barney, "Firm resources and sustained competitive advantage," J. Manage., vol. 17, no. 1, pp. 99-120, 1991.

[3] M. E. Porter, "Competitive strategy: Techniques for analyzing industries and competitors," Compet. Strateg. New York Free, 1980.

[4] R. Amit and P. J. H. Schoemaker, "Strategic assets and organizational rent," Strateg. Manag. J., vol. 14, no. 1, pp. 33-46, 1993.

[5] D. J. Teece and G. Pisano, "The dynamic capabilities of firms: an introduction," Ind. Corp. Chang., vol. 3, no. 3, pp. 537-556, 1994.

[6] D. J. Teece, "Explicating dynamic capabilities: the nature and microfoundations of (sustainable) enterprise performance," Strateg. Manag. J., vol. 28, no. 13, pp. 1319-1350, 2007.

[7] C. L. Wang and P. K. Ahmed, "The International Journal of Management Reviews," Dyn. Capab. A Rev. Res. agenda, vol. 9, no. 1, pp. 31-35, 2007.

[8] Y. Ou, L. Hsu, and S. Ou, "Social capital and dynamic capability driving competitive advantage: The moderating role of corporate governance," Int. Bus. Res., vol. 8, no. 5, pp. 1-18, 2015.

[9] M. F. D. Delgado, H. E. M. Ardila, and E. Ibarra, "Organizational Growth: Dynamic Capabilities as a Source of Sustainable Competitive Advantages-Literature Review," in 
Proceedings of the 9th International Conference on Intellectual Capital, Knowledge Management \& Organisational Learning, Bogotá, Colombia, Academic Publishing International Limited, 2012, pp. 77-84.

[10] L. Breznik and M. Lahovnik, "Renewing the resource base in line with the dynamic capabilities view: A key to sustained competitive advantage in the IT industry," J. East Eur. Manag. Stud., pp. 453-485, 2014.

[11] N. N. Abd Aziz and S. Samad, "Innovation and competitive advantage: Moderating effects of firm age in foods manufacturing SMEs in Malaysia," Procedia Econ. Financ., vol. 35, pp. 256266, 2016.

[12] L. S. Alinaghian, S. M. Gregory, and D. J. Srai, "Operationalising dynamic capabilities: A supply network configuration approach." University of Cambridge, 2015.

[13] F. T. Rothaermel and A. M. Hess, "Building dynamic capabilities: Innovation driven by individual-, firm-, and network-level effects," Organ. Sci., vol. 18, no. 6, pp. 898-921, 2007.

[14] V. Ambrosini, C. Bowman, and N. Collier, "Dynamic capabilities: An exploration of how firms renew their resource base," Br. J. Manag., vol. 20, pp. S9-S24, 2009.

[15] V. Ambrosini and C. Bowman, "What are dynamic capabilities and are they a useful construct in strategic management?," Int. J. Manag. Rev., vol. 11, no. 1, pp. 29-49, 2009.

[16] R. Makadok, "Toward a synthesis of the resource-based and dynamic-capability views of rent creation,” Strateg. Manag. J., vol. 22, no. 5, pp. 387-401, 2001.

[17] M. Zollo and S. G. Winter, "Deliberate learning and the evolution of dynamic capabilities," Organ. Sci., vol. 13, no. 3, pp. 339-351, 2002.

[18] T. V Adeniran and K. A. Johnston, "Investigating the dynamic capabilities and competitive advantage of South African SMEs," African J. Bus. Manag., vol. 6, no. 11, pp. 4088-4099, 2012.

[19] D. Li and J. Liu, "Dynamic capabilities, environmental dynamism, and competitive advantage: Evidence from China," J. Bus. Res., vol. 67, no. 1, pp. 2793-2799, 2014.

[20] K. M. Eisenhardt and J. A. Martin, "Dynamic capabilities: what are they?," Strateg. Manag. J., vol. 21, no. 10-11, pp. 1105-1121, 2000.

[21] S. A. Zahra, H. J. Sapienza, and P. Davidsson, "Entrepreneurship and dynamic capabilities: A review, model and research agenda," J. Manag. Stud., vol. 43, no. 4, pp. 917-955, 2006. 